\title{
EUROPAKO EKONOMI ELKARTEKO HIZKUNTZEN EGOERA ${ }^{1}$
}

\author{
Iziar Basterretxea, Iratxe Goikoetxea, Francisco Juaristi
}

Gaur egun, eta mundu osoan, demokrazia da goraipatzen eta baloratzen den sistema nagusia, kontzeptu honek onartzen dituen balioen artean aniztasuna eta gutxiengoen onespena eta bultzada egonik.

Europako Ekonomi Elkartea (EEE) osatzen duten estatuak demokrata agertzen dira banan banan harturik, eta Elkarteak berak, balio hauek onartzen dituela adierazten du. Honen oinarrian denon ezaugarriak onartuz eta babestuz, guztiona izango den esparru sozio-politikoa eraikitzeko helburua dago.

Dena dela, gauza bat balioak aldarrikatzea da eta beste bat, askoz zailagoa, baliook gauzatu eta garatzea. Gogoan izan behar da zailtasun hau gainditzeko eta aldarrikatutako balioak garatzeko indarrean datzala demokraziaren sendotasuna.

Kontestu honetan, Komunitateko estatuek puntu zehatz baten duten jokabidea aztertu gura izan dugu: Hizkuntza eta gizartearen arteko lotura, hain zuzen, kontuan izanik honako lotura hau estua dela eta hizkuntzan isladatzen direla gizartearen berezitasun eta aldaketak.

Europako Ekonomi Elkartea (EEE) osatzen duten estatu ezberdinetan aurkitzen ditugun hizkuntza minorizatuen egoeraren deskribapena aurkezten dugu. Zehatzago esanda, EEE-ko Estatuak eta Suitza, Europako erdigunean egonik eta bertako antolakuntza eredutzat hartu denez, interesgarria iruditu zaigulako Suitzako kasua ere aurkeztea.

Lanaren banaketari dagokionez, Estatu bakoitzeko hizkuntza ezberdinak eta hiztun kopurua aurkezten dugu lehenengo eta behin. Ondoren, bakoitzean aurkitzen ditugun hizkuntzen egoera juridiko-politikoa, hezkuntza egoera eta egoera kulturalaren berri emanik.

1 Lan hau egiteko ideia eta lehen pausuak 1991-1992ko Hizkuntza Minorizatuen Lege Egoerari buruzko doktoradutza ikastaroan eman ziren. 
Helburu nagusi bi izan dugu azterketa honi egiterakoan. Bata, inguruan ditugun hizkuntzen egoera ezagutzea, geure burua besapetik aterata. Eta bestea, egoera guztiok elkar jota, linguistikoki aniztasuna normaltzat izango duen gizartea jorratzeko bidean orain arte lortu ditugunak eta lortu beharrekoak zehaztea.

Azkenik esan gutxiengoen nazionalismoaren arazoa bizirik dugun momentu honetan, sentimendu nazionalistarekin bateratsu datozen hizkuntzen azterketak, Europan zehar bizirik dirauten nazio sentimendu hauek ulertzeko lagungarri izan daitezkeela.

\section{INGURUKO HIZKUNTZEN EGOERA}

\section{Alemania}

(79.000.000 biztanle)

Hizkuntzak eta hiztun kopurua ${ }^{2}$

—Daniera: 8.000 (591.399 biztanleko lurraldean).

-Frisiera: 9.000 (Bataz beste, 160.000 biztanleko lurraldean).

-Poloniera: 175.000 (Bataz beste).

\section{DANIERA $^{3}$}

Ez dago zenbaki ofizialik, 8.000 hiztunek erabili egiten dute baina 50.000 batek dakite. Danimarkarekiko muga ondoan bizi dira.

\section{Egoera juridiko-politikoa}

Daniera da onarturiko eskubidedun hizkuntza bakarra Alemania barruan.

Ez da ofiziala, baina Alemania eta Danimarkaren arteko hitzarmenaren arabera, lurralde horretan, auzitegietan eta administrazioaren aurrean hizkuntza aukera daiteke.

2 Bibliografian zehaztu ditugu txostenean eskeintzen ditugun datuen iturriak. Iturri nagusiak Malherbe, M. (1983) eta Europako ElKarteko TxostenaK (1986 eta 1990) izan dira, dena dela datuak ematerakoan kasu bakoitzeko iturri zehatzak aipatzen ahalegindu gara. Gai arazogarria da hau. Hontan ez dago adostasunik ezta zehaztasunik ere. Arrazoien artean egon daitezke errolden — administrazioen — ardura eza eta hiztunaren mugaketa zehatzaren zailtasuna.

3 Ikus. ElhuYAR: Munduko leku-izenak, Donostia, Elkar, 1991. Leku izenek Elhuyarrek emandako erizpideei jarraitzen dizkiete. Hizkuntzen izenak leku izenen gainean eratu ditugu. 


\section{Hezkuntza egoera}

Eskola pribatuak daude, Danimarkak hein haundi baten ordainduta. Danieraz hitz egin eta ikasten da, baina alemaniera ere ondo ikasi behar dute eta Alemaniako eskola-egitasmoak betetzen direla ziurtatu.

Eskola pribatu hauen kopurua gero eta handiagoa da haurtzaindegi zein maila ertainetan. Bestalde, lurralde honetako eskola publikoetan derrigorrezkoa da, ikasgai legez, daniera ikastea. Bertako gazte asko Danimarkako Unibertsitateetara doa.

\section{Egoera kulturala}

Danimarkarekiko lotura kulturalak oso biziak dira.

Komunikabideei dagokienean, hasieran ele bakarrez idatzirik zegoen eta geroago elebidun bihurtu den egunkaria dago, Danimarkak ordaindurikoa.

Ez dago irrati/TB ofizialik, baina Danimarkakoak heltzen dira eta lurralde honetarako programaketa berezia aurkezten dute.

\section{FRISIERA $^{4}$}

Jatorriz 60.000 frisiar izan arren, talde kontzientzia txikia dute. Aspaldian aukera bi eztabaidatu ziren, Danimarkan sartzea edo Alemaniarekin bat egitea.

Frisiar harrotasunaren aldeko agiria ere idatzi zen, herri honen izakera, kultura, hizkuntza eta eskubideak aldarrikatuz, eta ondoko herrien mirespena eta onarpen ofiziala eskatuz.

Azkenean Alemaniaren aldeko jarrera nagusitu zen. Alemaniak babestu eta onesteko hitza eman eta gero huts egin zien. Frisiarrek ez dute laguntza handirik Alemanian.

\section{Egoera juridiko-politikoa}

Gizarte-talde batzuk alde agertu arren, ez dauka inolako onarpen edo hitzarmen juridikorik.

\section{Hezkuntza egoera}

Ikasketa ertainetan, gurasoek eskatuta, frisierazko eskolak ematen dira. Gura izanez gero, eskaera hau edozein eskola mota eta mailatara luza daiteke. Ez da derrigorrezko ikasgaia inon.

\footnotetext{
${ }^{4}$ Frisiarrak Holandan eta Alemanian daude sakabanaturik. Herbeheretan bakarrik onartzen dizkiete oinarrizko eskubideak.
} 


\section{Egoera kulturala}

Elkarteak, antzerkiak, talde zientifikoak daude. Elizkizunak ere leku batzutan frisieraz dira. Aldizkari elebakar bat dago, dohain ( «Foriining for nationale Friiske» erakunde frisiarrak ordainduta). Irrati edo TB-rik ez.

\section{POLONIERA}

Ez dago datu ofizialik 1970ean bertako jakintsuek ${ }^{5}$ gutxi gora-behera 150/200.000 hiztun aitortzen zioten.

\section{Egoera juridiko-politikoa}

Ez dago onartuta. Aitzitik, noizean behin bazterkeria salatzen da.

\section{Hezkuntza egoera}

Ez dago eskola pribaturik eta, jakina, publikoetan ez du agerpenik. Bertako poloniarren elkarteek sortutako klaseak bakarrik ematen dira. Dena dela badaude, gai honetan ere, eskolen aldeko eskaerak.

\section{Egoera kulturala}

Laguntza eta onarpenik eduki ez arren, talde honetan nabaria da elkartzeko joera. Elkarte hauek aipatutako poloniera ikasteko klaseak antolatzeaz gain, onarpena, garapena eta Poloniarekiko lotura estuagoak eskatzen dituzte. Aldizkari pare bat ere ba dute.

\section{Belgika}

(10.000.000 biztanle)

Hizkuntzak eta hiztun kopuruak

-Frantsesa, ofiziala Valonian eta ofizialkidea Brusselan.

- Nederlandera, ofiziala Flandesen eta ofizialkidea Brusselan ${ }^{6}$.

- Alemaniera, gutxi gora-behera 100.000 hiztun (1986). Alemaniera erabiltzen den lurraldean ofizialkidea da frantsesarekin batera.

5 «Selon des évaluations faites par des savants» horrela agertzen da aipatutako Europako Elkarteko 1986ko txostenean (247. oa.), ez da zehaztapen gehiagorik ematen.

${ }^{6}$ Hizkuntza biak parekatuta daude hiztun kopuruetan, baina azken urteotan nederlandera nagusitzen ari da. 


\section{Egoera politiko-juridikoa}

Konstituzioak lau eremu bereizten ditu: 1. Nederlandarra, 2. Frantsesa, 3. Alemaniarra eta 4. Brussela (hiriburua, elebiduna) eta hiru komunitate kultural: frantsesa, nederlandarra eta alemaniarra.

1970. urtean Belgikako estatuaren egitura aldatu zenetik, parlamentariak talde frantses eta talde nederlandarrean banatuta daude, hizkuntza kontuan harturik. Alemaniera egiten den herrialdetakoak talde frantsesean sartzen dira.

Frantsesa da hizkuntza ofiziala alde frantsesean zerbitzu publiko guztietan. Nederlandera alde nederlandarrean. Frantsesa eta nederlandera, bata zein bestea, Brusselan.

Alde alemaniarrean alemaniera da hizkuntza ofiziala, legeak zehaztutako frantsesaren erabilpen osagarriarekin. Hala ere, norbanakoak, edonon dagoela ere, nahi duen hizkuntzaz zuzendu dakioke administrazioari, justiziakoari izan ezik.

Muga linguistikoan dauden udalek lege bereziak dituzte gutxiengoak babesteko. Alde alemaniarreko udal guztiek erregimen berezia dute, frantses gutxiengoak babesteko.

Brussela, hiriburua izanik, bestelako egoeran dago. Komunikabideak ele bietan egiten dira eta administrazioko lanpostu kopurua talde frantses eta nederlandarraren artean erdibanatzen da.

Legeei dagokienez, frantsesa eta nederlandera maila berean dagoz. Auzi guztiak hizkuntza bakarrez egiten dira eta akta elebidunek ez dute baliorik. Brusselan frantsesez nahiz nederlanderaz egin daiteke, beti ere akusatuaren hizkuntza kontuan hartuz.

\section{Hezkuntza egoera}

Herrialdeko hizkuntza derrigorrezkoa da eskolaurrean, oinarrizko eta bigarren hezkuntzan.

Elebiduna denez gero, Brusselan eskola frantsesak zein nederlandarrak daude, ikaslearen ama-hizkuntzak bata ala bestearen aukeraketa baldintzatzen duelarik. Edozein kasutan ere, bigarren hizkuntza nazionala ikastea derrigorrezkoa da.

Muga linguistikoan dauden udalek, lurraldez ez dagokien hizkuntza batez eska dezakete irakaskuntza, hizkunta horretako ikastetxea urrunegi dutela frogatu eta familia-buru nahikok eskatuz gero.

\section{Egoera kulturala}

Belgikan frantsesak eta nederlanderak bakoitzak bere lurraldea zehaztuta du, bertan ofizialtasun eta nagusitasun osoa izanik. Alemaniera- 
rekin aldiz ez da gauza bera gertatzen, bere lurraldean frantsesarekin batera dago eta. Zentzu honetan Belgikan alemaniera hizkuntza gutxitua da Alemaniak eta alemanierak duten indarrak, jarraituan ikusten dugun legez, gutxitasun hau murriztu arren..

Alemanieraren aldeko batzorde eta ikerketa guneez gainera, musika tradizioa, antzerki talde eta literatur lehiaketak ere aurki ditzakegu. Beste alderdi batetik alemanierazko liburuak soilik dituzten liburutegi asko ere badira.

Komunikabideei dagokienez, alemanierazko egunkaririk irakurriena Grenz-Echo da, 8.000 alerekin eta Neu-Belgien-en 1946tik alemanieraz bakarrik emititzen duen irratia dute, bertako administrazioak ordainduta. Alemaniako telebista eta irrati emisorak ere entzuten dira eta entzulego handia dute.

\section{Britainia Handia}

(57.500.000 biztanle)

Hizkuntzak eta hiztun kopurua

—Gaelikoa: Eskozian eskoziera da gaelikoaren forma lokala. 1981eko erroldako datu ofizialen arabera $79.307^{7}$ hiztunek hitzegiten zuten gaelikoa. Oso gutxi erabiltzen da.

Irlandan 1971 ko erroldaren arabera 789.429 pertsonak hitzegiten zuten gaelikoa ${ }^{8}$.

— Galesera: Galesen hitz egiten den hizkuntza da. 500.000 bat hiztun ematen diote.

Honez gain, gaur egun ahozko erabilera ia galduta dituzten honako hauek ere aipa ditzakegu.

-Frantsesa: Irla anglonormandarretan. Populazioa ia guztiz ingelestuta dagoela esan dezakegu.

-Kornuallesera: Komuallesen. Ahozko erabilera ia galduta egon arren badaude Kornualleseraren aldeko elkarte batzuk.

\section{GAELIKOA}

A) ESKOZIAN

\section{Egoera juridiko-politikoa}

Gaelikoa ia administraziotik guztiz kanpo geratzen da. Honela, administrazioan erabiltzea edo jakitea ez da derrigorrezkoa, dena dela gaelikoa dakiten funtzionariak hobesten dira.

7 Ibídem, EuropaKo ElKARTEKO tXOSTENA, 1986, 249. oa.

8 Ibídem, EUROPAKO ELKARTEKO TXOSTENA, 1986, 292. oa. 


\section{Hezkuntza egoera}

Gaelikoari bizirik eusteko baliabide nagusia hezkuntza dela esan genezake.

Estatutua eta 1980eko legearen arabera, gaelikoz hitz egiten den eskualdeetan hezkuntza gaelikoz izan daiteke, edozein mailatan. Eskola gehienetan gaelikoa asignatura autonomo bezala onartzen da, eskola batzuetan beste asignatura batzuk ere gaelikoz irakasten direlarik. Badira gaelikoz idatziriko testuliburuak ere.

Unibertsitateari dagokionez, Edinburgoko Aberdeen eta Glasgoweko unibertsitateek diploma arruntak, goi mailako diplomak eta hirugarren mailako kurtsoak gaelikoz egiteko aukera eskaintzen dute.

\section{Egoera kulturala}

Gaelikoak duen oztopo nagusia komunikabideetan ia soilik ingelesa erabiltzea da. Baina, beti ere, honako hizkuntza honi emaniko garrantzia tokian tokiko hiztun kopuruaren araberakoa da.

Gaelikoak literatur tradizioa daukala esan dezakegu, batez ere poesian, eta gaur eguneko literatura ere indartsu ari da. Beste alderdi batetik antzerki, musika eta ikerketek indarra dute.

Egunkari eta aldizkari elebakar zein elebidunak dituzte bai eta irrati publiko ta pribatuak: guztira 1981. urtean 650 orduz aritu ziren gaelikoz. Telebistari dagokionez: 1981.ean 29 ordu eman ziran gaelikoz.

\section{B) IPAR IRLANDAN}

\section{Hezkuntza egoera}

Eskola katolikoetan besterik ez da irakasten.

Belfasten lehen mailako eskola elebakar bat dago baina ez du jasotzen gobernuaren laguntzarik, Derry-n berriz dirulaguntzak hartzen dituen eskola bat dago.

Unibertsitatean Belfasteko Queen's University-k eta New University of Ulster-ek hizkuntza eta literatura gaelikoari buruzko kurtsoak dauzkate.

\section{GALESERA}

\section{Egoera juridiko-politikoa}

Ezagutza ofiziala dauka eta bertako Estatutuak agiriak galeseraz luzatzeko aukera ematen du; dena dela, administrazioan ez da derrigorrezkoa galesera jakitea.

Iragarpen publikoetan eta publizitatean galesera ugaltzen hasia da. 
Galeseraren 1967ko legeak (Welsh Language Act) ${ }^{9}$, auzitegietan galesera erabiltzeko eta agiriak galeseraz izateko aukera ematen du. Idazkia galeseraz eta ingelesez idatzita egon dadinean, ingelesezkoaren besteko eragina edukiko du. Zalantzarik sortuz gero ingelesezko testuari emango zaio lehentasuna.

\section{Hezkuntza egoera}

Lehen mailako 4 motatako hezkuntza ikus dezakegu:

a) Galesezko eskola tradizionalak, bereziki nekazal eskualdeetan: Asignatura guztiak galeseraz.

b) Eskola galesak, eskualde ingelestuetan. Lehenengo urteetan galeseraz, goiko mailetan gero eta gutxiagotan.

c) Ingelesezko eskola tradizional batzuetan: proiektu elebidun esperimentala burutzen ari da.

d) Beste ingelesezko eskola tradizionaletan: Galesera asignatura autonomoa bezala irakasten da.

Bigarren mailako hezkuntza ele bakarrez zein biez egitea aukera daiteke.

\section{Egoera kulturala}

Literatur tradizioa dauka, batez ere poesian eta gaur eguneko literatura ugari ere aurki dezakegu. Argitalpen gehienek dirulaguntza daukate (Tokiko agintarien ardurapean dauden Welsh Joint Education Committee-k eta Welsh Book Council-ek emandakoa).

Antzerki, musika eta galeserari buruzko ikerketa ugari aurki ditzakegu.

Komunikabideei dagokienez, egunkari elebakarrak eta elebidunak daude. Irrati arloan, irrati publiko eta pribatuen artean astero 65 orduz emititzen dute galeseraz. Eta telebistak astero 22 ordu ematen ditu galeseraz.

\section{Danimarka}

(5.300.000 biztanle)

Hizkuntzak eta hiztun kopurua:

-Alemaniera 20.000.

— Groenlandiera 40.000 (Inuit).

-Feroera 40.000.

9 Ikus Petschen Verdaguer, S. Las minorías lingüísticas de Europa Occidental: documentos (1492-1989). Vitoria-Gasteiz, Eusko Legebiltzarra 1990, 521. oa. 


\section{Groenlandiera ETA Feroera}

Groenlandia eta Feroe Irlek autonomi estatuak dituzte. Bertan, euren gobernuak, kasu berezietan nazioarteko harremanak ezartzeko eskubidea eta hizkuntzen onarpena egiten da.

Groenlandiera eta Feroera tokian toki ofizial dira danierarekin batera. Honek eguneroko ahozko erabilerari administrazio eta hezkuntza arloko erabileraren aukera gehitzen die. Dena dela estatutuak zehatz-mehatz aipatzen du hezkuntza arloan bertako hizkuntzak zein hizkuntzaz irakatsiko direla beti ere daniera baztertu barik ${ }^{10}$.

\section{Alemaniera}

Alemanierazko hiztunei alemanieraz hitz egin, ikasi, idatzi, eta inprimatzeko eskubideak zein elkartu, interesak defendatu eta Alemaniarekin harreman kulturalak izatekoak onartzen zaizkie baina ez dute lurralde-estatutu berezirik.

\section{Egoera juridiko-politikoa}

Tribunaletan eta egiaztagiri ofizialetan ez da erabiltzen. Ez da administrazio lanpostuetarako eskatzen.

\section{Egoera kulturala}

Elkarteak, literatura, egunkariak (elebakarrak) eta antzerkiak (amateurrak baina dirulaguntzekin) daude.

Irrati eta $\mathrm{TB}$ ofizialak ez du, noizean behin baino, saiorik ematen.

Herri-irratietan badute saioren bat.

\section{Eire (Irlanda)}

(3.600.000 biztanle)

Hizkuntzak eta hiztun kopurua ${ }^{11}$

—Gaelikoa: 1971ko erroldaren arabera 789.429 hiztun.

—Ingelesa: 3.450 .000 (1981).

10 Ibídem, Petschen Verdaguer 1990, 263. eta 315. oa.

11 Ibídem, EuropaKo ElKarteko tXostena, 1986, 301.oa. 


\section{Egoera politiko-juridikoa}

Eire sortu zenetik (1922), borondate edota aipamen politikoetan gaelikoak lehentasuna izan du. Lehentasun hau 1937ko Konstituzioan finkatuta dago ${ }^{12}$, gaelikoa hizkuntza nazional bakarra eta ofiziala bihurtuz, ingelesa bigarren hizkuntza ofiziala delarik.

Gaeliko eta ingelesez idatziriko lege-idatzietan, testu bien artean zalantzarik sortuz gero, gaelikoz idatzitakoak du lehentasuna.

Gaelikoz jakitea ezinbestekoa da administrazio publikoan lanpostua lortzeko. Eta auzitegiei dagokienez, nork bere burua defendatzeko gaelikoa erabiltzeko aukera dago, baina ezin da exijitu epaile edo abokatu gaelikodunik.

\section{Hezkuntza egoera}

Gaelikoa derrigorrez irakatsi behar da lehen eta bigarren mailako hezkuntzan, 1980. urtean lehen mailako eskolen \%4.7 gaelikoz elebakarra zen.

Bigarren mailako eskolei dagokienez, 1980-81ean eskolen \%3.6a zen elebakarra.

Bigarren mailako lau motatako eskolak ditugu: gaelikoa hizkuntza bakarra izan daiteke; ingelesa eta gaelikoa izan daitezke irakaskuntzarako tresna (batari zein besteari nagusitasuna emanik), edo gaelikoa beste ikasgai bat izan daiteke.

Unibertsitatean, Irlandako Unibertsitate Nazionalean, aritzeko gaelikoz derrigor jakin behar da. Hizkuntza eta literatura keltar eta gaelikoari buruzko kurtsoak gaelikoz irakasten dira eta beste asignatura batzuk ere hizkuntza honetan ikas daitezke.

Helduentzako gaelikozko kurtso ugari daude, baita irrati-telebistetan ere.

\section{Egoera kulturala}

Bide-ertzetako seinaleak elebidunak diren arren publizitatea, iragarpen ofizialak... ingelesez gaelikoz baino gehiagotan agertzen dira.

Zigilu gehienak gaelikoz daude eta dirupaperak elebidunak dira.

Elizan garrantzi handia dauka.

Komunikabideetan egunkari-aldizkari elebakar ugari eta aldizkari elebidun bat dute.

Irrati eta telebista nazionalek oso gutxi emititzen dute gaelikoz, programazioaren \%2.3a. Saioetako \%1.5a ele biez egiten dira.

\footnotetext{
12 Ibídem, Petschen Verdaguer 1990, 180 eta 185 . oa.
} 
Ekitalde kulturalei dagokienez, musika tradizio handia dago. Urtero, bataz beste 80 liburu gaelikoz argitaratzen dira.

\section{Espainia}

(39.000.000 biztanle)

Hizkutzak eta hiztun kopurua ${ }^{13}$ :

- Kataluniera: 6.000.000 hiztun.

—Galegoa: 2.453.664 hiztun.

-Bablea: 300.000 hiztun.

-Aranera: 4.000 hiztun (5.000 biztanle).

—Euskera: 600.000 euskaldun osoak ${ }^{14}$.

\section{KATALUNIERA}

Estatu Espainoleko hiru autonomia-elkartetan hitzegiten da: Katalunian, Valentzian eta Balearetan.

Egun, 9.000.000 lagun bizi dira kataluniera egiten den lurraldeetan. Hauetarik 6.000.000 katalunieraren hiztunak dira, gutxi gora-behera.

\section{A) KATALUNIAN}

\section{Egoera juridiko-politikoa}

Autonomia Estatutuak berezkotasuna aitortu eta ofizialtasuna zehazten dio, gobernu autonomikoak hizkuntza babestu eta bultzatzeko ardura duela.

Parlamentuko saioetan diputatu guztiek hizkuntza ofizial biak erabil ditzaketela ere, kataluniera baino ez dute erabiltzen.

Parlamentuak, Hizkuntz-Normalkuntzarako legea onartu zuen 1983.eko maiatzean, erabateko adostasunaz ${ }^{15}$. Lege honen arabera, Kataluniako berezko hizkuntza denez gero, katalunierak izan behar du Herri-Administrazioan erabiltzen den hizkuntza normala. Haatik, edozeinek erabil lezake Administrazioarekiko harremanetan. Dena dela eta herritarren ba-

13 Ikus. Europako ElKarteko tXostena 1990, 10 eta 45-50 oa. Espainiako kasua ere, zehatz-mehatz: SiguÁn, M. España plurilingüe, Madrid, Alianza Universidad, 1992.

14 Euskeraren egoera aparteko atalean aztertzen da, artikuluaren bigarren zatian.

15 Ibídem, Petschen Verdaguer 1990, 471. oa. 
tek horrela eskatuz gero Administrazioak berarekin gaztelera erabiliko du.

Herri-Administrazioko zenbait zerbitzu, Administrazio Zentralaren menpean dira; hemen, gaztelera da erabiltzen den hizkuntza, baina izatez herritarrekin katalunieraz egiteko gauza izan behar dute.

\section{Hezkuntza egoera}

Gobernu Autonomoak, hots, Generalitateak erabateko aginpidea du irakaskuntza arloan, Autonomia Estatutuaren bitartez. Normalizazio Legearen arabera:

- Katalunierak izan behar du irakaskuntzarako hizkuntza normala maila eta ikastetxe guztietan.

- Baina gurasoek eskubidea izango dute bere seme-alabentzat gaztelera eskatzeko irakaskuntza orokorreko lehen urteetarako, gaztelera bada euren familia-hizkuntza.

—Dena dela, Oinarrizko Heziketa Orokorra (O.H.O.) amaitutakoan, ikasle guztiek hizkuntza biak arazo barik erabiltzeko gai izan behar dute.

Gaur egun, eskolara doazen ikasleetarik \%30ek kataluniera du irakaskuntza-hizkuntza.

Goi-mailako irakaskuntzan: kataluniera da Unibertsitatean berezko hizkuntza, baina bai ikasleek, bai irakasleek ere, hizkuntza biak erabiltzeko eskubidea daukate. Eskolen erdia baino gehiago katalunieraz ematen dira.

\section{Egoera kulturala}

Urterik urte gehitu egiten dira katalunieraz argitaraturiko liburuak. Bataz besteko tirada 2.000 alekoa da.

Komunikabideetan: hiru egunkari kataluniera hutsean eta banaka bat aldizkari. Irrati-telebistei dagokienez, kataluniera hutsez emititzen duten hainbat emisora daude. TVEko kateetako bat katalunieraz da. TV3ek, Generalitatearen menpeko telebistak, saio guztiak katalunieraz egiten ditu.

B) VALENTZIA

Zenbaitek valentzieraren hizkuntzatasuna aldarrikatzen du, baina badirudi iritzi hori ematera bultzatzen duten arrazoiak politikoak direla, ez linguistikoak. 


\section{Egoera juridiko-politikoa}

Autonomia Estatutuan ofizialtasuna aitortzen zaio, gaztelerari bezalaxe. Valentziar Generalitateak hizkuntzon erabilera normal eta ofiziala bermatu eta bion ezagutza gauzatzeko behar diren neurriak hartuko dituela esaten da.

Erabakiok garatzeko, Parlamentuak «Valentzieraren irakaskuntza eta erabilerako Legea» onartu zuen 1983.ean ${ }^{16}$. Bertan, Valentziar Elkarteko berezko hizkuntza valentziera dela esaten da, lurralde gazteleratuan izan ezik; dena dela, hemen ere, herritarrek valentziera erabil dezakete Administrazioarekiko harremanetan.

Herri-Administrazioak valentziera erabiltzen du, soilik edo gaztelerarekin batera, kanpora begira: ezaugarri edo seinaleetan, herritarrentzako argibideetan, propagandan,... barrura begira, aitzitik gutxitan erabiltzen da, eta zerbitzuren baterako dago mugaturik.

Parlamentuan jakintzat hartzen da diputatu guztiek hizkuntza biak ulertzen dituztena, baina gaztelera da nagusi.

\section{Hezkuntza egoera}

Derrigorrez, astero lau orduz irakasten da valentziera, irakaskuntza maila guztietan eta zentru orotan, valentziera nagusi den gunean; lurralde gazteleratuan, ostera, ikastetxe batzutan besterik ez.

Unibertsitatean hizkuntza biak dira ofizialak. Eskolei dagokienez, $\% 20$ valentzieraz ematen dira.

\section{Egoera kulturala}

Arlo honi buruz datu gutxi daukagu. Argitaletxe indartsu samarrek valentzieraz eginiko liburuak argitaratzeari ekiten diote eta hainbat aldizkari daude, hedadura handikoak gainera.

Irratigintza alorrean, Estatu osoari dagozkion kate batzuk valentziera darabilte gehien bat lurralde barruko emisioetan.

Bertarako emititzen den Espainiar Telebistako emisoran valentziera erabiltzen da egunero ordu bete t'erdiz eta horrezaz gain telebista autonomikoa dute.

C) BALEARE IRLETAN

\section{Egoera juridiko-politikoa}

Autonomia-Estatutuak dio kataluniera dela Balearetako berezko hizkuntza, eta katalunierak, gaztelerak legez, hizkuntza-ofizialtasuna duela lurralde guztian.

\footnotetext{
16 Ibídem, Petschen Verdaguer 1990, 481. oa.
} 
Aurrekoari garabidea emateko, Baleareetako Parlamentuak «Normalkuntzarako Legea» onartu zuen 1986.eko apirilean, katalunieraren erabilpena bultzatzeko bai administrazioan, bai irakaskuntzan zein komunikabideetan $^{17}$.

\section{Hezkuntza egoera}

Balearetako Gobernuaren arabera, ikastetxe guztiek irakasten dute astero lau orduz kataluniera. Baina unibertsitateko ikasle batzuk berriki eginiko inkesta bateko datuek erakusten dutenez, ikastetxeetarik erdiak baino ez du betetzen lege hau; gainontzekoek erdizka betetzen dute, edo inola ere $\mathrm{ez}^{18}$.

Unibertsitateak berriz, Kataluniakoak eta Valentziakoak bezala, hizkuntza bien ofizialkidetasuna azaltzen du bere estatutuan; ikasgaietarik $\% 20$ edo \%30 gutxi gora behera katalunieraz ematen dira.

\section{Egoera kulturala}

Espainiako Telebistak bereziki lurralde honetarako prestatzen duen emisioetan tartetxo bat eskeintzen dio katalunierari.

Legeak aurrerakoia dirudien arren, emaitzak urriak dira: gaztelera oso hedaturik dago argitalpenetan, argibideetan, Parlamentuan... eta erabilera zeharo murritza da oraindik Herri-Administrazioko barne-erabileran, idatziz batez ere, eta urriago enpresa pribatuei dagokienez. Literatura-sariak antolatzen dira eta arloko produkzioa nahikoa garrantzitsu ei da.

\section{GALEGOA}

\section{Egoera juridiko-politikoa}

Autonomiaren hasierako urteetan Galiziako gobernuak hizkuntzarekiko interes gutxi erakutsi zuen. Talde nazionalistek eta radikalek erreibindikatzen zuten hizkuntza hori. Geroago, 1983. urtean aldaketa etorri zen, «Ley de Normalización lingüística» delakoa heldu zenean ${ }^{19}$.

17 Ibídem, Petschen Verdaguer 1990, 497.oa.

18 Ibídem, Europako ElKarteko 1990eko Txostena, 29. oa.: «Sin embargo una encuesta realizada recientemente por universitarios parecía demostrar que sólo la mitad de los centros cumplen plenamente esta exigencia los demás o no la cumplen o la cumplen sólo parcialmente. Y en cuanto a la posibilidad de utilizar el catalán como lengua de enseñanza no pasan de tres o cuatro en todas las Islas los centros que las aprovechan» Ez da aipatutako ikerketaren beste zehaztapenik ematen.

19 Ibídem, Petschen Verdaguer 1990, 511. oa. 
Galiziako estatutuan esaten da galegoa bertako hizkuntza dela eta bai galegoa bai gaztelania ofizialtzat hartu behar direla. Hau eremu desberdinetan ematen da. Parlamentuan, adibidez, parlamentariek hizkuntza biak ulertzen dituzten arren, adierazpen gehienetan galegoaz baliatzen dira. Administrazioan ere, paper ofizialak eta argibide guztiak galegoz eta gaztelaniaz eman ohi dira. Hemen herritar guztiek, nahi izanez gero, galegoz egin ditzateke gestio guztiak ahoz zein idatziz. Barruko ihardunean galegoa sarri erabiltzen bada ere, dokumentuetan eta horrelako komunikazio idatzietan oraindik erabilpen urria du.

\section{Hezkuntza egoera}

Hezkuntza Sailak gaur egun irakaskuntzan galegoa bizirik egon dadin ahalegin handiak egiten ditu eta eskolako maila guztietan galegoa irakastera behartzen du. Honetaz gain, galegoak izan behar du irakasteko tresna gutxienez asignatura batetan. Gaur egun O.H.O.ko zentru guztiek irakasten dute galegoa eta \%67ak gairen bat galegoz betetzen du. Batxilergo Balioaniztun Bateratua (B.B.B.) eta Lanbide Heziketan (L.H.) ordea badaude oraindik galegoa sartu ez duten zentruak eta \%30ak baino ez du gairen bat galegoz ematen.

Unibertsitatean, galegoa eta gaztelania hizkuntza ofizialak dira. Argibideak, informazioak galegoz zein gazteleraz ematen dira. Dena dela klaseak gazteleraz dira gehien bat (\%80) galegoz gutxi batzuk eman arren $(\% 20)^{20}$.

\section{Egoera kulturala}

1987. urtean bostehun liburu argitaratu ziren galegoz, tirada 1.000 eta 2.000 alekoa izanik.

Komunikabideetako hizkuntza: Galiziako egunkariek atal batzuk galegoz publikatzen dituzte, beste zenbait aldizkarik ere horrelatsu jokatzen dute. Irratien artean, Radio 4-k bere programaziotik zati handi bat galegoz emititzen du. Telebistak ekarri du aurrerapenik handiena. TV3 Galiziak ia-ia programazio osoa galegoz egiten du.

BABLEA

\section{Egoera juridiko-politikoa}

Asturietan erabilitako hizkuntza erromantzea. Batez ere nekazal arloari loturik egon denez, ez du pizkunde literariorik izan. Francoren garaian hizkuntza honen aldeko talde batzuk sortu ziren, baina ez zuten

20 Ibídem, Siguán, M. 1992, 224-228. oa. 
eragin politikorik sortu. Gaur egungo autonomi estatuak bablea Asturietako berezko hizkuntzatzat hartzen du eta babes osoa eskaini.

Beraz, bablea onetsi eta bultzatu nahi da; hala ere argi ikusten da ez dela aipatzen bablea hizkuntza ofiziala denik. Hauxe da benetako arazoa.

Hizkuntza politikarako bulego bat ezarri da, bablearen alde era daitezen ekimen guztiei laguntzeko.

\section{Hezkuntza egoera}

Irakaslegoari begira ikastaroak egiten dira eta bablea gero eta gehiago sartzen ari da. Asturiasko Gobernuaren Hizkuntz Politikarako bulegoak argitaratutako azkenengo datuek dioenez, 1985-1986ko O.H.O.ko ikasleetarik \%4ari bablea irakasten zaio.

\section{Egoera kulturala}

1980.ean sortu zen «Academia de la Lengua» izeneko erakundea, gero arau ortografikoak aurkeztu zituena. Gaur egun iskanbila handiak daude honen inguruan. 1984. urteko inkesta batek honako datuok azaldu dizkigu: 1.112.000 biztanleren artean \%51ak bablea ulertzen du; \%26ak hitz egiten du; \%33ak irakurtzen $\mathrm{du}^{21}$.

\section{ARANERA}

Kataluniako Val d'Araneko Okzitaniako gaskoieraren barietate berezia da.

Kataluniako parlamentuan 1983. urteko maiatzean onarturiko katalunieraren erabilpena indartzeko legeak zehazten du aranera Val d'Araneko hizkuntza dela eta arandarrek aranera ezagutu eta erabiltzeko eskubidea dutela ${ }^{22}$. Bestalde, Generalitatek eta arandar erakundeek hizkuntza honen ezagutza, erabilpena eta bultzapena babestuko ditu.

Haran horretako ikastetxeetan aranera irakatsi egiten da: astean bederatzi orduz aranera, eta araneraz ematen dira eskolak.

\section{Frantzia}

(57.000.000 biztanle)

Hizkuntzak eta hiztun kopurua:

-Alemaniar barietateak: Alsazian eta Lorenan. 1.260.000 hiztun.

-Bretainiera: Bretainian. 550.000 hiztun.

21 Ibídem, SiguÁN, M. 1992, 263. oa.

22 Ibídem, Petschen Verdaguer 1990, 479. oa. 
- Kataluniera: Roussillon lurraldean eta Sardinian. 200.000 hiztun.

-Korsikera: Korsika irlan. 162.500 hiztun.

—Nederlandera: Flandes frantsesean (Dunkerken). 100.000 hiztun.

-Okzitaniera: Hegoalde osoan zehar. 1.500.000 (Franko-proventzera barne ${ }^{23}$.

—Euskera: Euskal Herrian. 80.000 hiztun $^{24}$.

\section{Egoera juridiko-politikoa: Frantziako legeak}

Frantsesa hizkuntza ofizial eta nazional bakarra da. Dena dela, aipatu behar da Frantses estatuak ez diela onespen juridiko berbera egin gutxiengoen hizkuntza guztiei.

Bestalde, Konstituzioan edozein hizkuntzaz adierazteko askatasuna onartzen bada ere, orokorrean, Estatu frantsesak ez ditu ekonomikoki laguntzen hizkuntza minorizatuak.

Gutxiengoen hizkuntzei buruzko legedia aztertuz, zera esan dezakegu, 1985ean Herrialdeetako Hizkuntza eta Kultura Kontseilu Nazionala sortu zela herrialdeetako hizkuntza eta kulturei eutsi eta hauen bultzapenari buruzko arazoak aztertzeko Presidenteak eta Gobernuak hartutako erabakien barruan, beti ere ${ }^{25}$.

\section{Alemaniera}

1. Egoera juridiko-politikoa

Ez du inolako onespenik ez babesik ${ }^{26}$. Ez da ofiziala.

\section{Hezkuntza egoera}

Eskola publikoetan, alemaniera irakats daiteke eskolaurrean, eta lehen mailako hezkuntzan alemaniera aukerakotzat hartzen da (ikasgai autonomo bezala). Bigarren mailako hezkuntzan alemaniera asignatura autonomo legez ere irakasten da, baina ez da derrigorrezkoa.

\section{Egoera kulturala}

Komunikabideei dagokienez, egunkari elebidun eta elebakarrak dituzte, irrati elebiduna ere badute eta FR3 telebista publikoaren alsazie-

\footnotetext{
23 Ibídem, Europako Txostena 1986, 99. oa.

24 Euskeraren egoera aparteko atalean aztertzen da, artikuluaren bigarren zatian.

25 Ibídem, PeTSCHEN VeRdAGUER, 1990, 518. oa.

26 Ibídem 519. oa.
} 
razko saioak oso eskasak dira. Ikusleek Alemania, Suitza eta Luxemburgoko telebistetako saioak ikusteko aukera dute.

\section{BRETAINIERA}

1. Egoera juridiko-politikoa

Ez du inolako onespenik ez babesik. Ez da ofiziala ${ }^{27}$.

\section{Hezkuntza egoera}

Hezkuntzari dagokionez, 19 eskolaurretan eta 4 eskoletako lehen maila elebakarrak dira. Eskola elebidun batzuk ere badaude. Bigarren mailako irakaskuntzan baztertuta dago, eta zer esanik ez unibertsitatean. Arazorik larriena, eskaintza eskaria baino askoz txikiagoa izatea da.

\section{Egoera kulturala}

Ekitaldi kulturalak kontuan hartzen baditugu, bretainierari buruzko ikerketa ugari (aldizkari bat gramatika, fonologia eta dialektoei buruz) eta bretainieraz idatzitako liburuen bildumak aipatu beharra dago.

Komunikabideei dagokienez, egunkari elebakarrak/elebidunak eta aldizkari ugari aurki ditzakegu. Irratian, gobernuaren dirulaguntza duten irrati elebidunak dituzte. Telebista publikoak astero ordu t'erdi bretainieraz aritzen da.

\section{KATALUNIERA}

1. Egoera juridiko-politikoa

Ez dago onartuta Konstituzioan.

\section{Hezkuntza egoera}

Lehen mailako hezkuntza katalunieraz egiten da eskola askotan eta bigarren mailako hezkuntzan astero 3 orduz kataluniera irakasten da (teorian derrigorrez, praktikan aukera).

\section{Egoera kulturala}

Egoera kulturala aztertuz katalunieraren aldeko elkarte ugari dagoela esan dezakegu. Antzerki talde ugari eta musika tradizio handia.

\footnotetext{
27 Bretainiera, Kataluniera, Okzitaniera eta Euskararako, ibídem 317. oa.
} 
Komunikabideei dagokienez katalunierazko egunkaria/aldizkariak hegoaldeko Kataluniatik doazkie eta irrati pribatu bakarra dago guztiz katalunieraz. Irrati publikoak 3 orduz emititzen du katalunieraz.

\section{KORSIKERA}

1. Egoera juridiko-politikoa

Ez dauka onespen juridiko ofizialik.

\section{Hezkuntza egoera}

Eskolaurrean eta lehen mailako hezkuntzan, eskolen \%88an korsikera ikasgai bezela irakasten da.

Bigarren mailako hezkuntzan astero aukerako 3 ordu onartzen dira eskoletako \%80an.

Unibertsitate mailan, Niza eta Pariseko Unibertsitateetan bai hizkuntza bai honen kultura eta literatura irakasten dira.

\section{Egoera kulturala}

Ekitaldi kulturalei dagokienez, musika tradizio handiaz gainera, korsikeraren aldeko elkarte eta antzerki talde ugari dituzte.

Azkenik komunikabideak aztertuz gero, 2 egunkari elebakar eta 4 egunkari elebidun (publizitatea gutxitan agertzen da korsikeraz) aurkitzen ditugu. Irratiari dagokionez egunero ordu bete t'erdi korsikeraz ematen da. Eta telebistan FR3an astero ordu bete.

\section{NEDERLANDERA}

\section{Egoera juridiko-politikoa}

Ez du inolako onespenik ez babesik. Ez da ofiziala.

\section{Hezkuntza egoera}

Bigarren mailako hezkuntzan, nederlandera bigarren hizkuntza gisa aukera daiteke. Eskola liburuak eta helduentzako ikastaroak ere badira.

\section{Egoera kulturala}

Talderen batzuk nederlanderaren aldeko lanean dihardue. Musika eta antzerki-tradizioa, aldiz, eskasa da. 
Komunikabideetan, egunkari elebidun bat eta aldizkari elebidun bat aurki dezakegu. Irrati pribatu bat dago 1979tik, astero 8 ordu t'erdiz nederlanderaz aritzen dena.

\section{OKZITANIERA}

1. Egoera juridiko-politikoa

Ez du inolako onespenik ez babesik. Ez da ofiziala.

\section{Hezkuntza egoera}

Eskolaurrean eta lehen mailako hezkuntzan presentzia partziala ematen da, bigarren mailako hezkuntzan asignatura autonomo legez onartzen delarik. Badaude okzitanieraz idatziriko eskola liburuak eta helduek okzitaniera dohainik ikasteko aukera daukate.

\section{Egoera kulturala}

Ekitaldi kulturaletan, okzitanieraren aldeko elkarteak izateaz gainera, okzitanierazko antzerkiak zinemak eta musikak garrantzi handia dute. Gainera okzitanieraz liburu ugari argitaratzen da. Errepideetako seinaleak eta toponimoak hizkuntza bietan agertzen dira noizbehinka.

Komunikabideetan egunkari/aldizkari elebakar eta elebidun ugari dagoela ikusten dugu. Irrati publikoak egunero 15/25 minutu okzitanieraz kaleratzen ditu eta Irrati pribatu batzuetan okzitanierazko saioak aurki ditzakegu. Telebistari dagokionez FR3an telesaio kultural ezberdinak ematen dira.

\section{Grezia}

(10.000.000 biztanle)

Hizkuntzak eta hiztun kopurua:

- Turkiera: 59.000. (Azken balorapenak).

-Pomakera: 39.000. (Azken balorapenak).

- Valakiera: 40.000. (1951an).

-Eslaviera: 40.000. (1951an).

-Aravanitera: 23.000. (1951an).

Historian zehar asko izan dira gaurko Greziako mugetan bizi izan diren herriak. 
Azken urteotan bere independentzia lortzeko guda gogorrak egin behar izan ditu Greziako herriak, Turkiarren aurka besteak beste.

Grezian, hizkuntza mailan, barietate bi, goikoa eta behekoa, elizak eta herriak erabiltzen zituzten hizkuntza moten arteko gatazka ere luzea izan da, azkenean herriak bere moldea («Demotici») ezarri duen arte.

Guzti honengatik behar bada, Grezia gaur egun gogor agertzen da bere batasun etniko eta linguistikoaren alde eta hizkuntza bakarra onartu izana honen adierazgarri liteke.

Hau dela eta, 1951 an egindako erroldak herri eta hizkuntza ezberdinei emandako datuen ostean ez da zifra ofizial gehiagorik eskaini ezta bilatu ere, eta harrezkeroko erroldetan ez da horrelako galderarik egin.

1951ko datuak dira, bada, ofizial bakarrak. Hona hemen:

- Greziarrak guztira: 7.600.000.

— Turkiera: 92.443.

-Pomakera: 18.671.

- Valakiera: 39.855.

-Eslaviera: 41.017.

- Aravanitera: 22.736.

(10.000 hiztun baino gutxiago duten beste hizkuntza batzuk ere aipatzen dira).

Datuak, beraz, ez dira fidagarriak eta hasieran aipatutakoak, adierazten denez, adituek egindako azterketen arabera ematen dira. Dena dela, azken urteotan eraman den hizkuntz politika kontuan izanik, logikoena talde hauek gaur egun askoz murritzagoak izatea litzateke.

Baina hizkuntz politika orokorra laguntza eta onarpenik gabekoa izan arren, hemen ere aipatu behar da talde guztiak ez daudela egoera berean horri dagokionez.

\section{TURKIERA}

Eliza ortodoxoaren buruen egoitza Istanbulen dagoenez, Turkia eta Greziaren arteko lurralde mugak finkatu zirenean egoitza bere ohizko lekuan uztearren hitzarmen bat onartu zen. Turkiarrek bere lurraldeko greziar komunitatea onartu eta babestearen truke greziarrek berdin jokatuko lukete euren lurralde barruko turkiar komunitatearekin.

Honela, Lausanneko akordioaren arabera turkiar komunitatei berezko erlijioa, eskolak, aldizkari-egunkariak eta irrati saioak izateko eskubideak onartzen zaizkie ${ }^{28}$.

28 Ibídem, EuRopako ElKarteKo TXostena 1990, 55. oa. 


\section{POMAKERA}

Hizkuntzan eslaviarrak eta erlijioz musulmanak pomakarrek berezko historia kulturala dute, eta honen adierazle nagusia, gaur egun, hizkuntza da.

Grezian bizi eta greziera ezagutu eta erabili behar dute harreman formaletan. Musulmanak izan eta turkieraz jasotzen dituzte elizkizunak, irakaskuntza eta grezieraz ez datorren informazioa. Horrela, pomakerari famili eta lagun arteko harremanak baino ez zaizkio gelditzen.

\section{ESLAVIERA-VALAKIERA-ARAVANITERA}

Sorburu ezberdinetakoak izan arren - eslaviera hizkuntza eslaviarrak, valakiera latina eta aravanitera hizkuntza indogermaniarrak - hiru hizkuntz hauek antzeko egoera soziala jasatzen dute.

Orain arte, nekazal eta sakabanatutako guneetan irauteko aukera izan badute ere, gaur egun hirietarako joateak eta kultura idatziaren garapenak galzorian jartzen dituzte. Honetaz gain Greziak ez die inolako babesik ez ezagutzarik eskeintzen.

Egoera latz honetan hizkuntz gitxituen iraupenerako komunitate hauek gaur egun duten aukera ia bakarra valakiarrak hirietan erakusten ari diren elkartzeko eta euren eskubideen aitorpena eskatzeko joeratik etor liteke.

Amaitzeko, talde hauen kokapen geografikoari buruzko hitz bi: Turkiarrak eta pomakarrak Trazian daude; valakiarrak, Tesalia, Epiro eta Pindon; eslaviarrak Mazedonian eta aravanitarrak, erdi eta hego aldean.

\section{Holanda}

(14.600.000 biztanle)

Hizkuntzak eta hiztun kopurua:

—Frisiera 400.000 (Frisiarren lurraldeetan 592.000 biztanle dira) ${ }^{29}$.

\section{Egoera juridiko-politikoa}

Konstituzioan agertu ez arren, harreman juridikoetan eskubide batzuk onartzen dira, esate baterako, epaimahaiaren arabera, zilegia da auzitegietan frisieraz egitea.

\footnotetext{
29 Ikus. supra Alemania.
} 


\section{Hezkuntza egoera}

Eskola publikoetan gurasoek eskatuta eta irakasle nahikorik egonez gero haurtzaindegietan frisieraz egin daiteke. Oinarrizko eskoletan onartu eta ezarrita dago frisierazko heziketa.

Erdi eta goi mailako eskoletan ez da derrigorrezkoa. Batzutan bai, baina beste batzutan ezin da frisieraz ikasi.

\section{Egoera kulturala}

Frisiera hizkuntza bizia da, elkarteak, bibliotekak, antzerkiak, egunkari-aldizkariak (elebarrak eta elebidunak) irrati eta TB saioak daude.

Gaur egun ahozko erabilera nagusi izan arren, frisieraz idatziriko lehen testu ezagunak juridikoak dira (IX-XVI mendetakoak). Literatura idatzia ere, XIII mendetik ezagutzen da.

\section{Italia}

(58.000.000 biztanle)

Hizkuntzak eta hiztun kopurua ${ }^{30}$ :

- Albaniera: Kolonia desberdinetan 80.000 hiztun bizi dira.

- Alemaniera: Hego Tirol, Aosta, Vercelli, Novara, Belluno eta Udinen, guztira 292.450 hiztun.

-Esloveniera: Natisone, Torre, Erbezzo Resia haranetan eta Trevison, 52.170.

-Frantsesa: Aosta haranean eta Piamonten, 10.300.

- Greziera: Greziar koloniak gelditzen dira Regio di Calabria eta Lecce lurraldeetan, 12.500 hiztun, gutxi gorabehera.

- Kroaziera: Abruzzietan, 2.200.

- Retiera (erretorromanoa), Italia eta Suitzan erabilia, zenbait barietatek osaturikoa, nagusiak hauexek dira: engardinera (mendebaldeko barietatea), erdialdeko barietatea: guztira 51.600 hiztun; eta Friulera (ekialdeko barietatea): 625.000 hiztun. Zatiketa hori dela eta, inoiz gertatu da hizkuntzatzat hartu ez izana.

—Franko-proventzera: 48.000 hiztun $^{31}$.

\footnotetext{
30 Ibídem, Europako ElKarteko Txostena, 1986, Italiari buruzko atala 54-175. oa.

31 Ikus. supra Frantzia. Harrigarria bada ere Frantziako hizkuntzen artean ez dago honen aipamenik.
} 
-Kataluniera: 20.000.

-Okzitaniera: 50.000.

—Sardiniera: Sardinia irlan, 158.600 hiztun.

\section{Egoera juridiko-politikoa}

1985. urteko gutxiengo hizkuntzei buruzko lege-egitasmoaren arabera, Errepublikak herri ezberdin hauen kultura eta hizkuntza babesten du: kataluniar, germaniar, greziar, esloveniar eta zingaroena, baita dialekto hauek ere: ladinoa, franko-proventzala eta okzitanoa ${ }^{32}$.

Hezkuntzari dagokionez, lehen hezkuntzako eskoletan tokian tokiko hizkuntza irakatsi eta erabiltzeaz gainera, bertako ohitura eta usadioak irakatsiko dira. Eta bigarren mailako ikasketak egiterakoan, ikasle bakoitzak aukeratuko du zein hizkuntzaz nahi duen ikasi.

Era berean, herri sardiniar eta friularren hizkuntza eta kultura ere babesten da.

Alkarte ezberdinetako kultura eta ohiturak irakastea beharrezkoa da historia, geografia eta musika bezalako ikasgaietan.

Babestutako hizkuntzen lurraldeetan traduktorerik gabe italieraz egindako deklarazioek ez dute balio legalik.

Herritarrekiko harremanak hobetzeko asmoz, administrazioak tokian tokiko hizkuntza erabil dezake.

Irrati eta RAI telebistak komunitate ezberdinei zuzenduriko programak eman ditzake.

\section{Alemaniera}

1946. urteko Hego Tiroleri buruzko Italia eta Austriaren arteko akordioak (Gasperi-Gruber-ena) beste zenbait aukera eman zizkion alemanie$\operatorname{rari}^{33}$.

Akordio honen bitartez, alemanieraz hitz egiten duten Hego Tiroleko biztanleei, italieraz hitzegiten duten biztanleek dituzten eskubide berdinak ematen zaizkie, euren garapen kultural eta ekonomikoa babestu asmoz.

Honen bidez, lehen eta bigarren mailako ikasketak alemanieraz egiteko aukera dago. Irakasleak, beti ere, ama hizkuntza alemaniera dutenak izango direlarik.

Alemaniera, Italiera bezala, administrazioan erabiltzeko aukera: dokumentu ofizialetan, topografia e.a. Italianizatutako abizenak aldatzeko aukera. Eta azkenik, lanpostu publikoak lortzeko berdintasuna.

\footnotetext{
32 Ibídem, Petschen Verdaguer, 1991, 541. oa.
}

33 Ibídem, 221. oa. 
1959. urtean beste akordio bat sinatu zen Italia eta Austriaren artean. Honen bidez autonomiaren garapen eta minorien babesa bideratu nahi zen. Honela, alemanieradunek administrazioan eta auzitegietan alemanieraz hitzegiteko aukera dute; honez gainera, ama hizkuntza alemaniera duten irakasleekin alemanieraz ikas dezakete ${ }^{34}$.

1972. urtean sartzen diran berrikuntzak: Bolzanoko Estatu bulegoetan proportzionalitatea lortzeko araudia ${ }^{35}$.

-Funtzionariei dagozkienak: Aukeraketa egiteko komisioak eta hauen funtzionamendua.

- Hizkuntza gaitasuna frogatzen duen tituloa lortzeko pausoak.

-Funtzionarientzako hizkuntza ikastaroak.

- Bolzanoko administrazioan hizkuntza ezberdinak erabiltzen dutenen arteko proportzionalitatea gorde beharko da: Ladino, italiar eta alemaniarren arteko proportzionalitatea kontuan hartu beharko da.

KROAZIERA

Trieste lurraldeari buruzko Memoranduma Londresen izenpetu zen 1954. urtean Italia eta Jugoslaviaren artean, Inglaterra eta EEBBk ere parte hartu zutelarik ${ }^{36}$. Hitzarmen honetan Jugoslavia eta Italian bizi ziren gutxiengo jugoslaviar eta italiarren babesa lortu nahi zen.

Itun honen arabera, gutxiengo ezberdinen kultura eta izakera etnikoa kontuan hartu beharko da:

a) Beraien hizkuntzaz idatzitako egunkaria izateko eskubidea.

b) Talde etniko ezberdin hauen erakundeei beste talde etnikoen erakundeek dituzten eskubideak aitortzea.

c) Ama hizkuntzaz ikasteko aukera. Eskola hauetako programak ez dira umeen abertzaletasuna biztu eta bultzatzeko erabiliko.

Euren hizkuntzaz hitz egiteko eskubidea dute, edozein momentutan, baita administrazioarekiko harremanetan ere, eta admistrazioaren erantzuna hizkuntza horretan jasotzeko eskubidea aitortzen zaie. Administrazioaren erabaki edo txosten guztiek itzulita egon beharko dute. Era berean herri, kale eta abarren izenek hizkuntza bietan idatzirik egon behar dute.

Erabakion jarraipena egin eta bertan zehazturikoak betearazteko batzorde bat sortu zen.

\footnotetext{
34 Ibídem, Petschen Verdaguer 1990, 323 eta 327. oa.

35 Ibídem, 527. oa.

36 Ibídem, 227. oa.
} 


\section{Luxemburgo}

(400.000 biztanle)

Hizkuntzak eta hiztun kopurua:

-Luxenburgera: 400.000.

-Alemaniera: 400.000.

-Frantsesa: 400.000.

Biztanle gehienak hirurak ezagutzen dituzte. Luxenburgera da hizkuntza nazionala, 1984ko legearen arabera ${ }^{37}$.

Legeak frantsesez idazten dira eta hizkuntza honek agintzen du itzulpenak daudenean, baina erakunderen batek aginduren bat beste hizkuntza baten eman ezkero, hizkuntza hori izango da nagusi interpretazio arazoak sortutakoan.

Estatua, jasotako eskutitzei erantzutean, hauen hizkuntza berbera erabiltzen ahaleginduko da.

Malhelben ustetan honelaxe banatzen dira hizkuntzen rolak: etxean luxenburgera, kulturan eta lehen irakaskuntzan alemaniera, administrazioan eta goi-zikloetan frantsesa ${ }^{38}$.

\section{Portugal}

(10.000.000 biztanle)

Hizkuntzak eta hiztun kopurua:

—Mirandera: 15.000 hiztun.

\section{Egoera}

Portugal, Mendebaldeko Europako eta Europako Elkarte Ekonomikoaren herririk bateratuena da, hizkuntzari dagokionez.

Ipar eta hego aldeen arteko ezberdintasunak egon arren, hauek, beste edozein hizkuntzatan gertatzen diren ohizko aldakiak dira eta ezin dira hizkuntza ezberdintzat jo.

Berditasun egoera honetako salbuespena mirandera dugu. Hau, Espainiako mugan dagoen Miranda de Duero lurraldeko herrietan hitzegiten da. Ez du agerpen idatzirik ezta laguntza edo babespen ofizialik ere. Ahozko eta lagunarteko hizkuntza legez erabiltzen du 15.000 hiztun inguruk. Hizkuntza erromantzea da.

37 Ibídem, 546. o.a.

38 Malherbe, M., Les langages de l'humanité, Paris, Seghers, 1983, 423. o.a. 


\section{Suitza}

(6.500.000 biztanle)

Hizkuntzak eta hiztun kopurua ${ }^{39}$ :

-Alemaniera: 15 Kantoitan hitz egiten da (guztira 23 kantoi dira), Suitzako iparralde erdian eta ipar ekialdean. 4.000.000 hiztun.

- Frantsesa: Friburgo, Valais, Vaud, Ginebra, Neuchatel eta Jura-n. 1.500.000 hiztun.

- Italiera: Tesinon hitz egiten da. 750.000 hiztun.

- Retiera ${ }^{40}$ : Grisonesen ${ }^{41}, 52.000$ hiztun.

Erabilpena:

Alemaniera hedatuz doa Friburg, Valais eta Tesinon.

\section{Egoera juridiko-politikoa}

Printzipio Konstituzionala hizkuntzaren askatasuna eta lurraldetasunaren printzipioan oinarritzen da, nahiz eta printzipio bi hauek kasu askotan kontraesanean egon.

Legedia oso konplexua da, federazio mailako legediak kantoi mailan ere eragin juridikoak dituelako.

FEDERAKUNDE MAILAKO ONESPENA 1938an, alemaniera, frantsesa eta italierari nazionaltasuna eta ofizialtasuna aitortu zitzaizkien, erretierari berriz nazionaltasuna baino $\mathrm{ez}^{42}$.

Irakaskuntzari dagokionez retiera erabat bazterturik dago Lanbide Heziketan, Eskola politekniko federaletan eta batxilergoan; antzerako bazterketa jasoten du italierak.

KANTOI MAILAKO ONESPENA. Kantoi «heterogeneo» direlakoetan, maila ofizialeko ezagutza dute bertako hizkuntza ezberdinek, dena dela errealitatean ez da legeak zehazturikoa betetzen. Beti ere, hizkuntzaren bat besteei nagusitzen zaie administrazioan.

Lurraldetasunaren printzipioak zehazten du zein hizkuntzaz argitaratuko diren legeak, dekretuak, administrazioko agiriak... zein izango den irakaskuntza publikoa eta auzitegietako hizkuntza, baina, azken puntu honetan, auziko alderdiek hizkuntza aukeratzeko eskubidea dute.

Ondorio bezala zera esan dezakegu, Suitzako hizkuntza-legeak ez daudela garatuta. Horrek esan nahi du oraindik ez dagoela liskar gogorrik,

\footnotetext{
39 Ibídem, Malherbe, M. 1983, 429. oa.

40 Ikus. supra Italia.

41 Ibídem, Petschen Verdaguer, 1990, 143. oa.

42 Ibídem, 186. oa.
} 
baina ekonomia, politika eta kulturaren menpe agertzen dela hizkuntza arazoa.

\section{EUSKERAREN EGOERA}

Euskera gaur egun hizkuntza erromaniko biz inguratuta bizi da: gaztelania eta frantsesa. Hizkuntza biok aspalditxo sartu ziren euskal eremuan eta esan daiteke gaur ez dagoela ele bakartzat euskera duen herririk, zenbait udalek horren aldeko joera hartu arren. Euskaldun hutsak ere (erderarik ez dakitenak) urriak dira ${ }^{43}$.

\section{Hiztun kopurua}

\section{Euskal Elkarte Autonomoan ${ }^{44}$}

Era bitako euskaldunak berezi beharko genituzke: euskaldun osoak eta ia-euskaldunak. Azken hauek guztiz euskaldundu gabeko euskaldunberriak eta euskera erdi ahaztuta duten euskaldunzaharrak lirateke. Hau kontuan harturik, hiru multzo bana ditzakegu:

\begin{tabular}{lrc}
\hline Guztira: & 2.052 .300 & $\% 100$ \\
Euskaldun osoak & 548.100 & $\% 26,7$ \\
Ia-euskaldunak & 399.800 & $\% 19,5$ \\
Erdaldunak & 1.104 .500 & $\% 53,8$ \\
\hline
\end{tabular}

\section{NAFARROAKO ELKARTEAN ${ }^{45}$}

Nafarroan, berriz, honako emaitza hauek erakutsi zizkigun 1986ko erroldak:

\begin{tabular}{lrc}
\hline Guztira: & 501.989 & $\% 100$ \\
Euskaldun osoak & 50.953 & $\% 10,1$ \\
Ia-euskaldunak & 26.478 & $\% 5,27$ \\
Erdaldunak & 424.558 & $\% 84,5$ \\
\hline
\end{tabular}

43 Hizkuntza jakitearen muga ipintzea zaila da eta honek ere oztopatzen du elebakarren kopuru zehatza ezagutzea. Dena dela, gaur egun diren euskaldun elebakarrak atso-agure eta umeen artean aurkitzen ditugu.

44 1991ko zentsuko datuak.

45 1986ko zentsuko datuak. 
IPARRALDEAN

Frantziako Estatuko erroldetan ez da jasotzen hizkuntzari buruzko daturik. Guk ditugun datuak SIADECOk 1988an Iparraldeko euskeraren egoerari buruz eginiko txostenetik atera dira ${ }^{46}$. Datu orokorrak erabili beharrean 3.825 lekuko aukeratu ziren. Hona hemen txostenean zehazturiko zenbait datu (Laginako ehunekoak):

\begin{tabular}{lcc}
\hline & Mintzatzeko & Idazteko \\
\hline Hizkuntz gaitasuna & & \\
Zehaztugabeak & 2,4 & 7,5 \\
Ezer ez & 23,4 & $47,-$ \\
Hitz batzuk & 8,2 & 7,3 \\
Nekez & 8,2 & $12,-$ \\
Nahikoa ongi & 16,8 & 16,1 \\
Oso ongi & $41,-$ & 10,1 \\
\hline
\end{tabular}

Herrialdeka, euskera OSO ONDO eta NAHIKO ONDO egiten dutenen proportzioa bateratu ezkero ehunekorik haundiena BAXENABARRAN dago $(\% 68,2)$, ondoren ZUBEROA $(\% 53,7)$ doakiola eta azkenik LAPURDI geratzen delarik $(\% 48,2)$.

\section{Egoera juridiko-politikoa 47}

\section{ESPAINIAKO ESTATUAN}

Konstituzioak zehazten du gaztelania Estatu osoko hizkuntza ofiziala dela, espainol guztiek ezagutu behar eta erabiltzeko eskubidea dutela. Gainontzeko hizkuntzak ofizial izan litezke, dagokien Elkarte barruan, bertako Estatutuek hala zehaztuz gero.

\section{A) Euskal Autonomia Elkartean}

- Autonomia Estatutua.

- Euskera Elkarte barruan hizkuntza ofiziala dela zehazten du.

46 SIADECO. Euskararen egoerari buruz diagnosia eta geroari buruz hautabide edo eszenarioak, Donostia, 1988. Iparraldeari dagokionez lan honen laburpena ikusteko: LARRAÑAGA, I «Euskara Ipar Euskal Herrian» JAKIN 54 iraila-urria 1989 121-147. oa.

47 Ibídem, Petschen Verdaguer, 317, 378, 383, 437-471 eta 518. oa. 
—Euskararen Erabilera Arautzeko Oinarrizko Legea.

- Euskeraren kultura arloko zabalkunde edo normalizazioa eta estandarizazioa bultzatu nahi ditu, hizkuntza-eskubide eta betebeharrak zein hauek bermatzeko neurriak zehaztuz.

- Bestelakoak, esaterako Administrazioan euskeraren erabilera zehazteko eta funtzionarientzako hizkuntza-eskakizunak erabakitzeko aginduak.

B) Nafarroan

-Euskeraren Legea.

- Gaztelera da Nafarroa osoko hizkuntza ofiziala. Euskera eremu euskaldunetan baino ez da izango ofizial.

\section{FRANTZIAKO ESTATUAN}

Hizkuntza bakarra hartzen da ofizialtzat, frantsesa. Beste hizkuntzaren baten erabilera onartuko da hitz egiteko gai diren funtzionariak izanez gero. Iparraldeko lurraldeetan ez dute euskeraren gaineko lege berezirik.

\section{Hezkuntza egoera ${ }^{48}$}

Eskolak: XIX. mende erditik aurrera euskal eskolaren beharra ikusi zen, baita eskoletan euskeraz egiteko eskabideak egin, baina Gobernu Zentralek ez zuten eskaririk onartu.

1889an Hegoaldeko lau Diputazioak elkartu egin ziren irakasle-izendapenetan konpetentzia autonomoa eskuratu nahian. Proposatzen zen eskolaren ezaugarriak: pedagogia-arloan berrizalea eta hizkuntzaren aldetik euskalduna.

Honen ondorioz gerra aurretik Bizkaiko Auzo-Eskolak eraikitzen hasi ziren: lehen Ikastolak. Hamarkada baten (1920-1932) 125 Auzo-Eskola eraiki zen. Euskera irakas-tresna izan zen Primo de Riveraren Errejimena gogor paratu arte (1925).

Donostiako lehen ikastola 1914ean edegi zen eta Nafarroakoa, berriz, 1933an Euskeraren Adiskideak Elkargoak bultzatuta.

48 Hezkuntzari buruzko datuak honako liburu honetatik harturikoak dira: INTXAUSTI, J., Euskara, euskaldunon hizkuntza, Eusko Jaurlaritza, Vitoria-Gasteiz, 1990. 
Gerra ondoko lehen ikastola 1954ean eratu zen Donostian eta 1957an Bilboko lehena. 1960tik aurrera gora egin zuten ikastolek: Gipuzkoan (Orixe, 1958), Bizkaian (R. M. Azkue, 1962/Lauro, 1972), Nafarroan (1964), Araban (Olabide, 1963) eta azkenik Iparraldean (1969).

Euskal Autonomi Elkarteak (EAE) hiru hizkuntza-eredu sortu ditu irakaskuntzarako: D ereduan, irakaskuntza euskeraz ematen da, eta espainiera ikasgai bat da; B ereduan, irakaskuntza euskeraz eta espainieraz egiten da, gai kopura hizkuntza bion artean erdibanaturik; A ereduan irakaskuntza guztia erderaz egiten da euskera ikasgaietako bat dela. Lehenago $\mathrm{X}$ eredua ere bazen, euskerarik gabekoa (gaur egun ia desagerturik dago).

Ereduetako ikasle kopurua (1992-93 ikast. $)^{49}$

\begin{tabular}{lrc}
\hline & Ikasleak & Ehunekoa \\
\hline A + X Ereduak & 114.727 & $\% 44$ \\
B Eredua & 74.002 & $\% 28$ \\
D Eredua & 72.838 & $\% 28$ \\
Guztira & 262.567 & $\% 100$ \\
\hline
\end{tabular}

Iturria: Eusko Jaurlaritzako Hizkuntza Politikarako Idazkari Nagusiaren Agerraldia, berak eskatuta, Eusko Legebiltzarreko Iraskunde eta Herrizaingo Batzordearen aurrean, Vitoria-Gasteiz, 1992.

Nafarroan ere hizkuntza-eredu desberdinak sortu dira Eskolaurre, Oinarrizko Hezkuntza Orokorra (OHO), Batxilergo Balioaniztun Bateratua (BBB), Unibertsitatera Bideratzeko Ikasturtea (UBI) eta Lanbide Heziketarako (LH). Euskal eremuan eredu bi hartu dira: B ereduak irakaskuntza euskeraz du, eta gaztelera ikasgaia da baita zenbait ikasgaitarako tresna ere; D ereduan ikasgai guztiak izango dira euskeraz «gaztelera» izan ezik. Eredu biok eremu mistoan ere erabil daitezke guraso eta haurrek eskatuta eta Administrazioak hala erabakiko dituen kasuetan (euskeraren irakaskuntza ez da izango derrigorrezkoa, borondatezkoa baino).

Herri-eskola eta Ikastoletako datuak honako hauek dira (1988-89): Eskolaurrean eta OHOean 10.243 ikasle daude B/D ereduetan eta 823 BBB eta UBIn, D ereduan. (Baina euskerazko irakaskuntzadun zentrurik gehienak eskolaurrekoak dira).

49 Eskolaurre eta OHOko ikastetxe guztiak hartu dira kontuan. 
Bai Nafarroan bai Euskal Autonomi Elkartean Irakaskuntza Ertainetan eta Unibertsitatean euskera askoz murritzagoa da. Euskal Herriko Unibertsitateak orokorrean erdaraz egiten du bizitza, baina badu euskerataz arduratzeko Erretoreordetza.

Iparraldeko egoera askoz latzagoa da: 1987-88. ikasturtean gurasoek seme-alabentzako aukeraturiko hizkuntza-ereduak honela banatzen dira (Ama-eskolan):

—Euskeraren irakaskuntzarik ez: \%68,07

—Euskera ikasgai: \%26,78

- Irakaskuntza elebiduna: \%2,3

- Irakaskuntza euskeraz: \%3,02

Ikasturte beretan lehen mailan ikasten ari ziren 25.000 ikasleetarik 1.500 baino gutxiagok egiten zituen ikasketak guztiz edo erdizka euskeraz.

Eskola publikoetan Saran eta Donibane Lohitzunen bakarrik aurki dezakegu hezkuntza elebiduna Honetaz aparte, lehen mailako hezkuntzan bigarren hizkuntza bezala aukera daiteke.

Beste alderdi batetik Seaska hezkuntza antolakuntzak indar handiagoa hartzen ari da apurka apurka.

Unibertsitatean, euskara eta euskal Literaturako katedra dago Bordeleko Unibertsitatean eta Baionan Euskara Unibertsital Diploma aurki dezakegu.

\section{Egoera kulturala}

\section{A. Literatura eta Liburugintza}

Euskal Literaturgintza berandu sortu zen, euskeraz argitaraturiko lehen liburua Bernart Etxeparek 1545ean kaleraturiko poesia-liburua izanik, gaurko datuen arabera. Euskal literatura berandu sortu eta are beranduago garatu egin zen: XVI. mendea eta XIX.aren artean ezer gutxi idatzi zen euskeraz literaturari begira XIX. mendearen amaieran eta $\mathrm{XX}$.aren hasieran etorri zitzaion berpizkundea. Gizaldi honetan zehar izandako gorabehera batzuk alde batera utzita, gaur gorantz egiten ari dela esan daiteke, bai literaturgintza bera, bai gainontzeko liburugintza ere: gero eta gehiago dira euskeraz idatziriko liburu zientifiko, kulturalak, e.a. ${ }^{50}$.

50 Azken urteotan argitaraturiko liburu kopuruaren berri gura izan ezkero, jo JAKIN aldizkarira 42-43, 46, 50, 63 zenbakietara. 
B. KomuniKabideAK ${ }^{51}$

Idatziriko kazetaritza

Frankismoak Hegoaldeko lau hiriburuetan hamalau egunkariren desagerpena ekarri zuen; beste hamarrek segi zuten kalean. Ondoren beste lau egunkari berri agertu ziren (Bilbon 2, Donostian 2), baina euskerak ez zuen lekurik bertan.

Ez zen onartzen pertsona izenik euskeraz, eta euskerazko eskelarik ipintzekotan erderazkoa ere ordaindu beharra zegoen. 1962ra arte ez zen euskerazko artikulurik onartu. 1966an Diario de Navarrak orrialde bat eukeraz ateratzeari ekin zion.

Euskal egunkaririk ez zegoenez gero, idatzizko prentsa astekarietan egiten zen: Herria (Iparraldekoa, 1944), Zeruko Argia (Donostia, 1963), Anaitasuna (Bilbo, 1967), e.a.

Frankismoaren ondoren Deia eta Egin agertu ziren egunero tartetxo bat eskeintzen ziotena euskerari. Geroago asteroko euskal periodikuak agertu izan dira: Hemen (1986), Eguna (1986) eta Zabalik (1986). 1990ean gaurko euskal egunkari bakarra kaleratu zen: Egunkaria. Aldizkarien artean Argia da ezagunena eta zabalduena.

\section{Irratia eta Telebista}

Lehen euskal irrati-emisorak Elizaren babespean sorturiko herri-irratiak izan ziren: Segura (1956), Tolosa, Loiola, Arrasate eta Arrate (1959) Gipuzkoan; Barakaldo Bizkaian; Beruete edo Irurita Nafarroan. Gehienbat parrokiakoak ziren eta euskerari lekua egin zioten. Loiola hasi zen programa osoak euskeraz ematen (1961).

Eusko Jaurlaritzak EITB sortu zuen, beronen barruan Euskadi Irratia eta Euskal Telebista ditugula. Euskal Telebistaren lehen kateak 3.888 ordu dauzka programatuta euskeraz (1989); ETB-2k 1.829 ordutik 118 ematen ditu euskeraz.

Nafarroako Gobernuak 1985ean Radio Televisión Navarra izeneko erakundea sortu zuen nafar telebista gauzatzeko asmoz baina garestiegia zela eta, azkenean ez zen asmo hori burutu. Euskal Telebistarekin elkartzeko asmorik izan omen bazuten ere, ez zen ezer gauzatu bide horretatik. Azkenean, udalek ipinitako antenen bidez, Euskal Telebista ikus daiteke Nafarroa osoan.

«Tele Navarrak» («Tele Norte»ren antzekoa, TVEren menpekoa) astean bost egunetan duen ordubeteko saioan, egunean euskeraz 30 segunduko laburpena egiten du.

51 Ibídem, InTXAUSTI, 1990. 
Euskadi Irratiako saioak euskeraz dira egunero 24 orduz Donostian, Bilbon berriz gazteleraz egiten ditu.

Iparraldean ere jaio dira irratiak: Milafrangako Gure Irratia (1981), Irulegiko Irratia (1982) eta Xiberuko Boza (1982), osorik edo gehienik euskeraz.

Gainera Euskal Herrian tokiko 47 irrati libre ziharduten 1988an: hauen emanaldietan ere euskerak bere lekua izan ohi du.

\section{AZKEN BURUTAPENAK}

Aurkezturiko hizkuntzen deskribapen honetatik atera dezakegun lehen ondorioa Estatu elebakarrik ez dagoela da. Eleaniztasuna lurraldeko hizkuntzak erizpide direnean agertzen da, hau da, kasuan kasu aztertutako lurraldeetan berezko diren hizkuntzak. Lurraldekoak ez direnak kontuan hartuko bagenitu arazoa areagotuko litzateke. Definizio arazoak aurkitzen ditugu. Herri eta komunitate ezberdinen historiak askotan gurutzatu egiten dira aldi baten eta gero banandu (edo alderantziz). Zein da, azken baten, hizkuntzen lurraldetasuna finkatzeko erizpidea?

Gutxienez 16.000.000 pertsonak hitz egiten du ofiziala ez den, gutxitua dagoen edota gutxiengoarena den hizkuntzaren bat, kontuan izanik kopuru honetan ez direla sartu Belgikako frantsesak, ez Luxenburgo eta Eireko komunitateak. Hizkuntza gutxitua eta gutxiengoen hizkuntza gauza ezberdinak direla argi dagoela ematen badu ere, zeintzuk dira elkarren arteko harremanak? Eta, horretaz gain, zein da hizkuntza bat edo komunitate bat horrela sailkatzeko neurria?

Arazoak konpondu ez arren, argi dago estatutu juridikoak duen garrantzia. Hizkuntzaren sailkapen legalak itzelezko eragina du berau garatzeko orduan. Garbi agertzen da hau, adibidez Suitzan edo Alemania eta Holandan. Suitzan retiera nazionala da baina ez ofiziala, eta desberdintze honek hedapena mugatzen dio. Bestetik frisiarren egoera Holandan eta Alemanian horren desberdin izatea adierazgarria da. Estatutu edo sailkapen legal bakoitzak ondorio sozio-politiko-ekonomiko ezberdinak dakartza hizkuntzan.

Baina hizkuntzen sailkapen legala ez da halabeharrez egiten: askoz aukera gehiago eman ohi zaizkio lurralde bateko gutxiengoaren hizkuntza izan arren, beste Estatu baten babesa duen hizkuntzari. Esaterako, hauxe izango litzateke Danimarkako alemanieraren kasua edota Suitzako italierarena. Esan dezakegu beraz, gitxiengo mota ezberdinak daudela, batzuk aurrera egiteko aukera dutenak, eta beste batzuk garatzeko aukera urrikoak. 
Ezin dugu aipatu barik utzi datuen eskasia eta dauzkagun apur hauen fidagarritasunik eza. Interesgarria litzateke errolda eta zentsuetan datuak jasotzeko bidea ematea bai eta datuak biltzeko erizpideak bateratzea.

Amaitzeko, gai honetan oinarrituz, EEEren demokrazia maila neurtu behar izango bagenu ezin izango genioke aldeko epairik eman. Ildo honetatik uste dugu, arazo honetan ere, luzarora, eskubideak bideratzea eta indarrean jartzea, zapaltzen eta izkutatzen ahalegintzea baino «merkeagoa» eta oparoagoa dela.

\section{BIBLIOGRAFIA}

Askoren Artean: Euskadi en el proyecto Europa, Madril, Centro de Estudios Ramón Areces, 1991.

ASKOREN ARTEAN: Euskal Herriko Atlasa, Donostia, Erein, 1982.

ASKOREn ArteAn: Nueva Enciclopedia Larousse, Barcelona, Planeta, 1984.

BILBOKo UdAla: Euskara Bilbon, Bilbo, 1991.

CoBreros Mendazona, E.: El régimen jurídico de la oficialidad del euskara, Oñati, HAEE-IVAP 1989.

- El euskara en el estatuto vasco, Oñati, HAEE-IVAP, 1989.

- (Bateragilea): Euskararen lege-araubideari buruzko jardunaldiak, Oñati, HAEE-IVAP, 1990

COMMISSION DES COMMUNAUTES EUROPEÈnEs: Les minorités linguistiques dans les Pays de la Communaute Europeène. Luxembourg, Office des publications Oficielles des Communautes Europeènes, 1986.

- Las minorías lingüísticas en la CEE: España, Portugal, Grecia. Resumen del Informe. Luxemburgo, Oficina de Publicaciones Oficiales de las Comunidades Europeas, 1990.

ECHENIQUe ElizOndo, M. T: Historia lingüística vasco-románica, Paraninfo, Madril, 1987.

EUSKO JAURLARITZA: Soziolinguistikako mapa 1986. urteko erroldaren araberako Euskal Autonomi Elkarteko azterketa demolinguistikoa, Gasteiz, 1989.

GOBIERNo DE NAVARRA: Distribución de la población navarra según el nivel de euskera, Pamplona, 1988.

INTXAUSTI, J.: Euskara, euskaldunon hizkuntza, Gasteiz, Eusko Jaurlaritza, 1990.

JAKIN: Euskara Nafarroan, 56, 1990.

- Iraultza Frantsesa 1789-1989, 51, 1989.

Malherbe, M.: Les Langages de L'humanité, Paris, Seghers, 1983.

Obieta Chalbaud, J. A.: Las lenguas minoritarias y el derecho. Bilbao, Mensajero, 1977.

Petschan Verdaguer, S.: Las minorías lingüísticas de Europa Occidental. Documentos. (1492-1989), Vitoria-Gasteiz, Eusko Legebiltzarra, 1990.

PIZZORUSso, A.: Ordenación legal del plurilingüismo en los estados contemporáneos. Barcelona. Consejo Consultivo de la Generalidad de Cataluña. 1983. 
SÁNCHEZ CARRIón, J. M.: El estado actual del vascuence en la provincia de Navarra (1970), Iruña, Institución Príncipe de Viana, 1972.

SIADECO: Euskararen egoerari buruz diagnosia eta geroari buruz hautabide edo eszenarioak, Donostia, 1988.

SiguÁn, M.: España plurilingüe, Madrid, Alianza Editorial, 1992.

UrRutiA, A.: Euskara legebidean, Bilbo, Deustuko Unibertsitatea, 1990. 